\title{
Ramses IIs Unpablished Part of an Offering Table
}

\section{in Tell el-Muqdâm}

\section{Khaled Eltaly\&Saad Elsyd Mansor Abdalla '}

In this article, the researcher has chosen a monumentss that has not published before, has been found in Tell el-Muqdâm ${ }^{2}$ preserved in stores of Tall ar Rub', it is recorded in Dakahlia Antiquities Area, under No. 3300 , the offering table represents to the king Ramses II , loss last part of it, has been chosen at this table

1) Khaled Eltaly, Professor - Egyptology department - Faculty of Arts - Kafr Elsheikh University and D. Saad Elsyd Mansor Abdalla, director of north dakhlia ,Ministry Tourism and Antiquities

${ }^{2}$ ) Tell el-Muqdâm is located near el-Muqdâm village Mit Ghamr center, far away from Mit Ghamr city about ten kilometers, Located north of Cairo at about $50 \mathrm{~km}$, An area of about one hundred acres . Naville carried excavations in Tell el-Muqdâm in 1892 , Naville said that high hill up to 60 feet, Then carried excavations in the hill again , These excavations brought out monuments due to different periods continued the old Kingdom until the Greco-Roman period.

C.A.,Redmount and R. Friedman,, Tales of a Delta Site: The 1995 Field Season at Tell el-Muqdam, JARCE 34 (1997), 57-83. (map, plans, fig., ill.).

God Mihos was the chief god in the city, his sacred animal lion ,the city was the capital of the nome of the eleventh nomes of Lower Egypt, Tell el-Muqdâm was named in ancient Egypt $t 3-r m w$ which means " land of the fish", Maybe land name of fish t3- rmw mentioned in coffins texts, Spell 158 " Coming into existence when God Sobek created the fish trap ".

Yoyotte, J., La ville de "Taremou" (Tell el-Muqdâm), BIFAO 52 (1953), 190 .

Tell el-Muqdâm has been great importance during Middle Kingdom and New Kingdom , especially during King Ramses II reigns, Where we found him statue is made of red granite, there are inscription reads, Ramses II beloved of Ptah .

É.,Naville, Ahnas el Medineh with chapters on Mendes, the nome of Thoth, and Leontopolis , London , 1894 , P.31 pl.6

in Dondit village which is near of Tell el-Muqdâm discovered small statue of red granite to (of) King Ramses II also , in Dondit discovered number of large and small block, there are inscription to King Ramses II , It may have been moved from Tell elMuqdâm .

C.,Edgar, Report on the demolition of Tell Sheikh Nasreddin .ASAE 13 (1914) 123 Importance city emphasized and its historical role continued during the Late Period, especially during the dynasty 22 , because the tomb of Queen Kama mother of the King "Osorkon IV" discovered at Tell el-Muqdâm in 1915, Maybe Tell el-Muqdâm is seated Dynasty 23, and the place where they have taken residence of their bodies .

C. A .,Redmount,. and R. Friedman, The 1993 Field Season of the Berkeley Tell elMuqdam Project: Preliminary Report, Newsletter of the American Research Center in Egypt, New York 164 (Winter 1994), 1-10. (plans, fig.).

Tell el-Muqdâm named during Ptolemaic period Leontopolis, meaning " city of the Lions " attributed to local lion-god Mihos who changed his name to god Miysis during Ptolemaic period.

J., Yoyotte, Le paradoxe de Léontopolis (méthodes moyens et contexte actuel en matière d'archéologie urbaine), L'Égyptologie en 1979. 1, 297-302. 
for many reasons, including .Offering table represents modern monuments discovered ,where the table was discovered in 2011, through excavations season in Tell el-Muqdâm ${ }^{3}$, besides that offering table represents unique monuments to Pharaoh Ramses II found it many years in Tell el-Muqdâm, offering table have significant artistic value, where it is polished very well, besides it is different from in figure tables discovered to Ramses II , there are inscription on offering table external sides in ( with) ancient Egyptian language . Besides, the inscription does not kind represent of offerings forms which is usually written on offering tables . Offering tables was made from sandstone, a method of relief inscription , the table dimensions as follows : High-table $31 \mathrm{~cm}$, Side length B $75 \mathrm{~cm}$, Side length D $70 \mathrm{~cm}$, Width $46.5 \mathrm{~cm}$, Inside cavity $14.5 \times 15.5$. Maybe represents the missing part of about 25 to $30 \mathrm{~cm}$ at the back of the table. This means that the table was almost a length of about $100 \mathrm{~cm}$. There were previous studies about Offering Table dating to King Ramses II, including :

Petrie, F., Tanis. - London , 1885-1888. 9-24 pl.1 ,66 plan 105; Kamal, A., Tables d'offrandes. Le Caire : l'IFAO, 1906-1909. (CG ; 23001-23256) ;

Kitchen, K. A., Ramesside Inscriptions. Historical and Biographical. II.Oxford,1977, $456 ; 782-783$;

Offering tables represented importance to the ancient Egyptians, it was dedicated to putting food as an offering to the gods, recorded it recognized forms such as offerings form which can be written on the surface of the table or register on the edges of the table or register on the sides around the table ${ }^{4}$.

It is important to note that it was one of the means to feed the deceased in the other world using offering tables which began to expansion in the Egyptian tombs in the late first intermediate period and middle kingdom, where tables were made modest and often a few inscriptions ${ }^{5}$ has appeared as types of

3) S , Abdalla , Report excavations of Tell el-Muqdâm, season 2011.

¿) A., El - Sawi,"some objects found at Tell Basta (season 1966-67) ASAE LXIII, 1979,155-159

5) Niwinski,A," plateaux d offrandes maisons d ames .Genes evolution et fonction dans le culte des 
offering tables called Petrie offering trays ${ }^{6}$, was put it offerings food presented to deceased in other world, offerings represented mostly foodstuff consisting of head of cow, onions ,bread and other,

There is also found channels on offering tables allow descended water and fluids from surface table to bottom . Petrie linking between this kind of offering tables and Soul houses ${ }^{7}$.

Has been known in ancient Egypt three types of offering tables, firstly : Offering

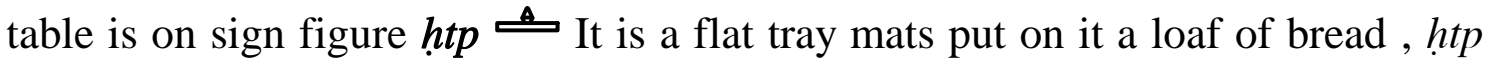
means also peace, quiet and satisfaction, these descriptions are wishes deceased for himself in other world until (even) he can confrontation difficulties in this world , and this sign was used in words such as "offering" or "altar", may this kind tables have been started appearance in Old Kingdom ${ }^{8}$. secondly : Offering

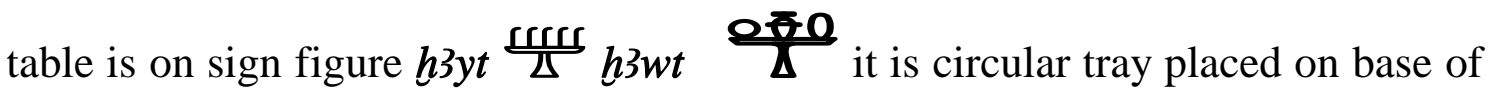
cylindrical figure or rectangular, it is put various kinds food of offerings ${ }^{9}$.

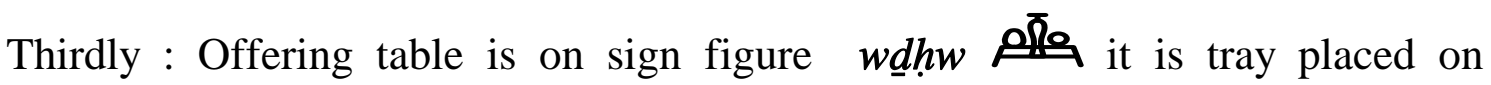
pregnant with four-legs or it is table with four legs ${ }^{10}$. Both kinds second and third appeared in many offerings views on the walls of temples and tombs ${ }^{11}$.

\section{Archaeological significance}

Offering table, which we are going to study important monuments is discovered to King Ramses II in Tell el-Muqdâm . where we did not discover to king Ramses II any monuments in Tell el-Muqdâm for a long time, most of what was discovered in this Tell was dating Greek and Roman period, this table and other discovered monuments in Tell el-Muqdâm emphasizes interesting King Ramses

`) F., petrie, Gizeh and Rifeh, London ,1907,16

v) Ibid , pp.16-17; L ̈̈, VI, p809-810

${ }^{8}$ ) Wb ,III ,183-6 ; M.,Maha,Untersushungun zu opfertaeln, HAB,17(1982) 38

9 ) A-C.,Dia,Alters and offerring tables,denkmaler des alten Reiches III, le

Caire,1987,p.10; Wb

$$
\text { , III, 226-5 }
$$

'.) $\mathrm{Wb}, \mathrm{I}, 393-7$

') L.,Klebs ,Die Reliefs des alten reichec, Heidelberg, 1915,pp-130-132 
II in this city, maybe it's emphasizes that existence of a temple or shrine built by King Ramses II in this city, Table-like coffin, It is a rectangular table, it is hollow in inside, there's a hole inside to collect the fluids . Fig.,1, There are ancient Egyptian Language inscription on sides of table .

A

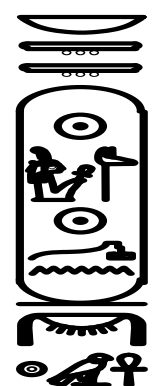

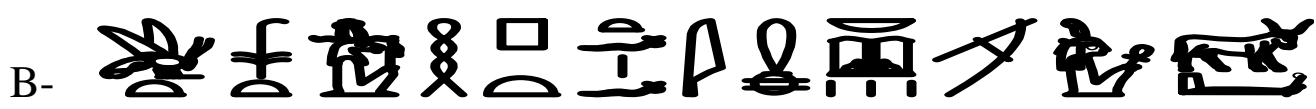

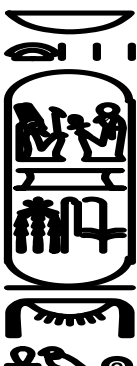

C- +80

D-

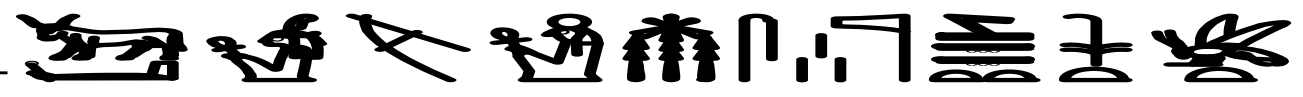

Transliteration

A - nb t3wy (wsr $\left.-m 3^{\top} t-r^{\top} s t p-n-r^{\top}\right)\left({ }^{\top} n h h h r-n b w\right.$

B- $k 3$ nht mry m3't $n b$ hbw-sd ${ }^{12}$ mi it ff pth t3-tnn nswt-bity /III

$\mathrm{C}-n b h^{\complement} w\left(r^{\mathrm{e}}-m s-s w-m r y-i m n\right)\left({ }^{`} n h h h r-n b w\right.$

D- $k 3 \quad n h t^{13}$ mry $m 3^{\complement} t, r^{\odot}$ msw ntrw grg t3wy nswt-bity

Translation

A -- Lord of appearance User-Ma'at-Re Setep-en-Re , Long live, golden Horus,

B- May the strong bull, beloved of Ma'at, the lord of the Sed-festivals , like his father Ptah-Tanen, the King of Upper and Lower Egypt .

C - Lord of the Double-Land Ramses-Meri-Amen, Long live, golden Horus ,

'r) A.H.Gardiner,Egyptian Grammar. $3^{\mathrm{e}}$ ed., Oxford, (1957) 495

${ }^{1 \%}$ ) Ibid., $§ 55.51$ 
D- May the strong bull, beloved of Ma'at, Re who gave birth to all gods, who furnished the Double-Land , the King of Upper and Lower Egypt .

\section{Commentary}

1- B $: k 3$ nht strong bull or victorious bull, sculpted on the table abbreviated, $k 3 n h t$ it's appeared abbreviate in many inscriptions royalty, when it was a full writing, write in this form an attribute ascribed to the pharaoh and symbol for the pharaoh since earliest times ${ }^{14}$, This title has been entered in the Horus name of King Tuthmosis III and King Amenhotep III 15

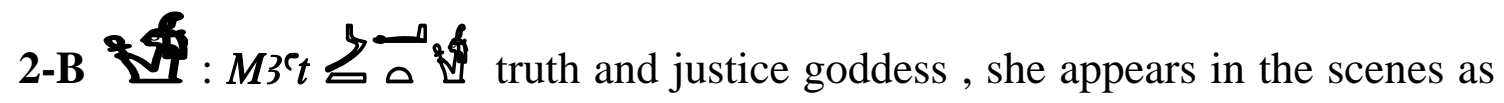
figure female standing or sitting above her head feather and in her hand sign life \& $\{h h$ or scepter $I w 3 s$, according to some texts that Maat son of the god Ra, maat represents regime materialize on the earth, it is put founded by god $\mathrm{Ra}$, Then the god $\mathrm{Ra}$ assigned justice action to king sit down on the throne. The king was presented in ritual maat also ${ }^{16}$.

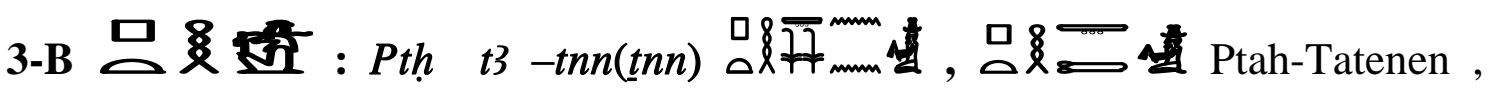
Meaning " Ptah is (owner) rising land " 17 Tatenen, Meaning " rising land " Ptah-Tatenen god is appeared on a monuments with human body wearing a crown of ram horns and two feathers . Tatenen, Meaning " rising Land " . Maybe it was the first appearance of the god Tatenen in middle kingdom , Tatenen god symbolizes to the eternal hill, means that he is creator god, described as lord of the time, described as a fertility god, he is described as the protection of the king in the afterlife also , maybe Tatenen god is oldest gods

\footnotetext{
Is) Ibid., $\$ 55.51$

10) R.,Gundlach, Weltherrscher und Weltordnung. Legitimation und Funktion des ägyptischen Königs am Beispiel Thutmosis III. und Amenophis III , Franz Steiner Verlag, 1992

${ }^{16}$ ) C., Leitz, Lexikon Der Agyptischn Gotter Und tterbezeichnungen , 7 vol., OLA 110- 116, vol.,III , ( Leuven 2002 ), 222- 227 ; E.,Teeter, The Presentation of Maat. Ritual and Legitimacy in Ancient Egypt, Chicago , 1997

${ }^{17}$ ) M.,Gorg, Königliche Eulogie. Erwägungen zur Bildsprache in Ps 8,2, Biblische Notizen, München 37 (1987), 38-47.
} 
worshiped in Memphis, maybe have been association in Egyptian belief between two gods Ptah and Tattenn during the dynasty $19^{18}$.

While Ptah god appears on most a monuments in this figure 므ㅇㅛㅛ ${ }^{19}$, Ptah is the most important deities of the Egyptian religion ${ }^{20}$ Maybe worshiped in ancient Egypt since the time of the first dynasty, Maybe Ptah was worshiped in Egypt during pre-dynastic period, Ptah was associated with one of the creation theories in ancient Egyptian religion, Ptah is god of arts, crafts and industries, The priest of the temple of Ptah carrying the title of "supervisor of craftsman's ", according to some texts Ptah, lord of Memphis, maybe there was his temple south of Memphis , So Ptah named Pth, rsj-inb.f " Ptah-South-of-his-Wall ", Triad Memphis consisting of Ptah ,his wife Sekhmet and his son Nefertem ${ }^{21}$.

4-в $h b$-sd : Sed- festivals, sculpted on the table abbreviated, when it was writing a full written with several figures, including $\mapsto \vec{\square} 22$ a celebration represents occasion sitting King on the throne festival was held all thirty years, some kings was celebrated repeating this festival many times, although he did not rule more than thirty years, Scientists have various opinions about numeral Sed- festivals times which king Ramses II was celebrated, Some scientists believe that King Ramses II , where he was celebrated Sed- festival about thirteen times almost.$^{23}$ It has been prominent manifestations Sed- festival set up obelisks which are symbols of the sun god Ra 24

$\left.{ }^{18}\right)$ H. , te Velde ,De zegeningen van Ptah-Tatenen. Een egyptische koningsinscriptie uit de 13e eeuw v. Chr.,Schrijvend Verleden, 355-360.

${ }^{19}$ ) Wb ,I ,565 ; R.0.Faulkner, A Concise Dictionary of Middle Egyptian , ( Oxford, 1962 96.

${ }^{20}$ ) Wb ,I ,565 ; R.0.Faulkner, Op.Cit., 164

${ }^{21}$ ) J.,Quagebeur ,Une épithète méconnaissable de Ptah, Livre du centenaire, 61-71 (2 fig.).

${ }^{r}$ ) R.0.Faulkner, A Concise Dictionary of Middle Egyptian, ( Oxford, 1962 ) 164

${ }^{\mathrm{r}}$ ) E. Meyer, Gesch II , I , P. 139 ;J.,Breasted, Temples of Lower Nubia , AJSL, 23 , 1906 , 5 ; Sethe , ZAS , 26 (1898 ) 64; O'.,David \& E., Cline, Amenhotep: Perspectives on his Reign, University of Michigan, 1998,16

${ }^{\ulcorner}$) M.,William , The Sed Festival : A Problem in Historical Method , MDAIK 37, 36976 


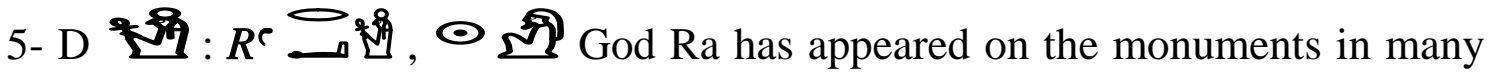
figure, the sun disk is famous of those figure, also Ra shows human body with a falcon or ram-headed, his worship have flourished since the Fourth Dynasty almost, King became son of Ra and governs in his name, according to ancient Egyptian religion the god Ra is father of gods and founding ownership . ${ }^{25}$

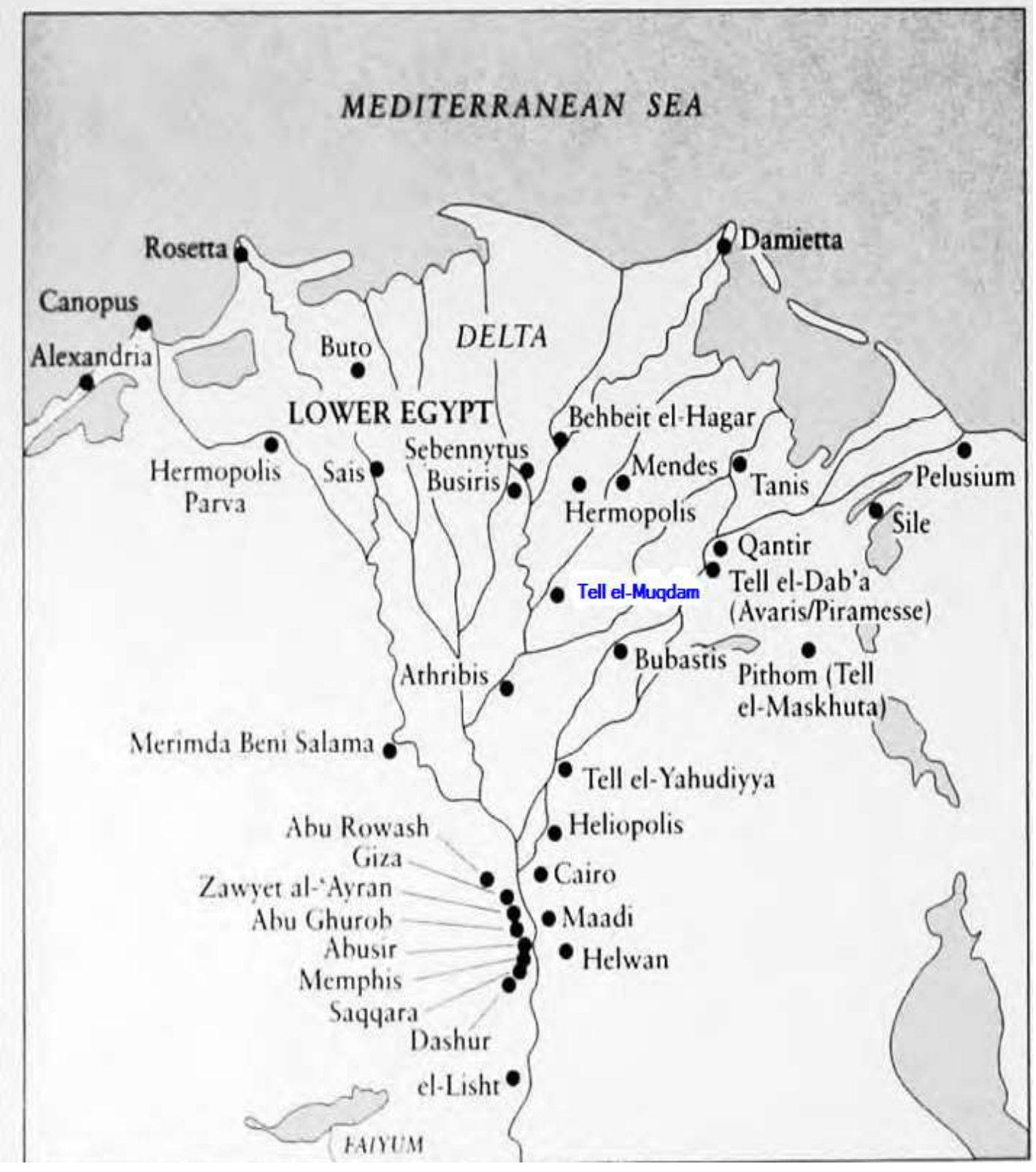

Map of Tell el-Muqdâm between lower Egypt cities

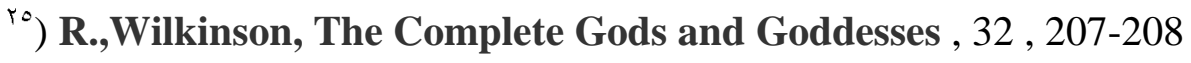




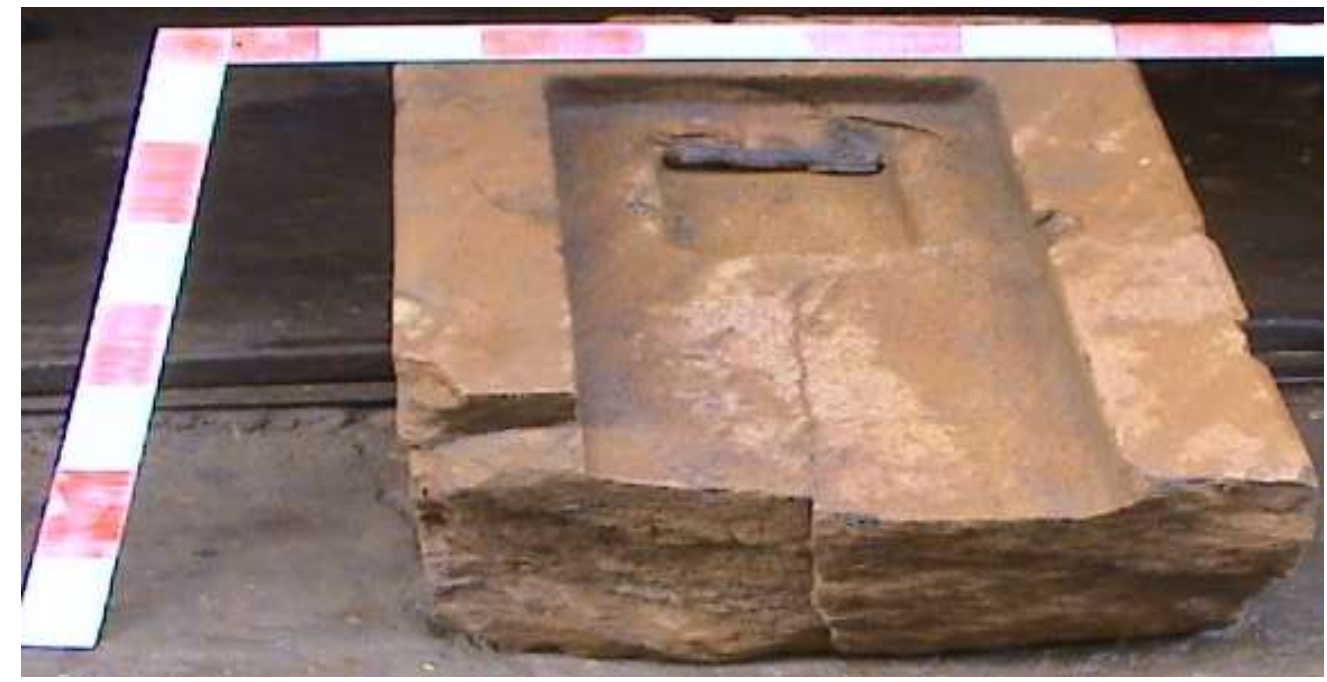

Fig.,1. Tell el-Muqdâm Offering Table
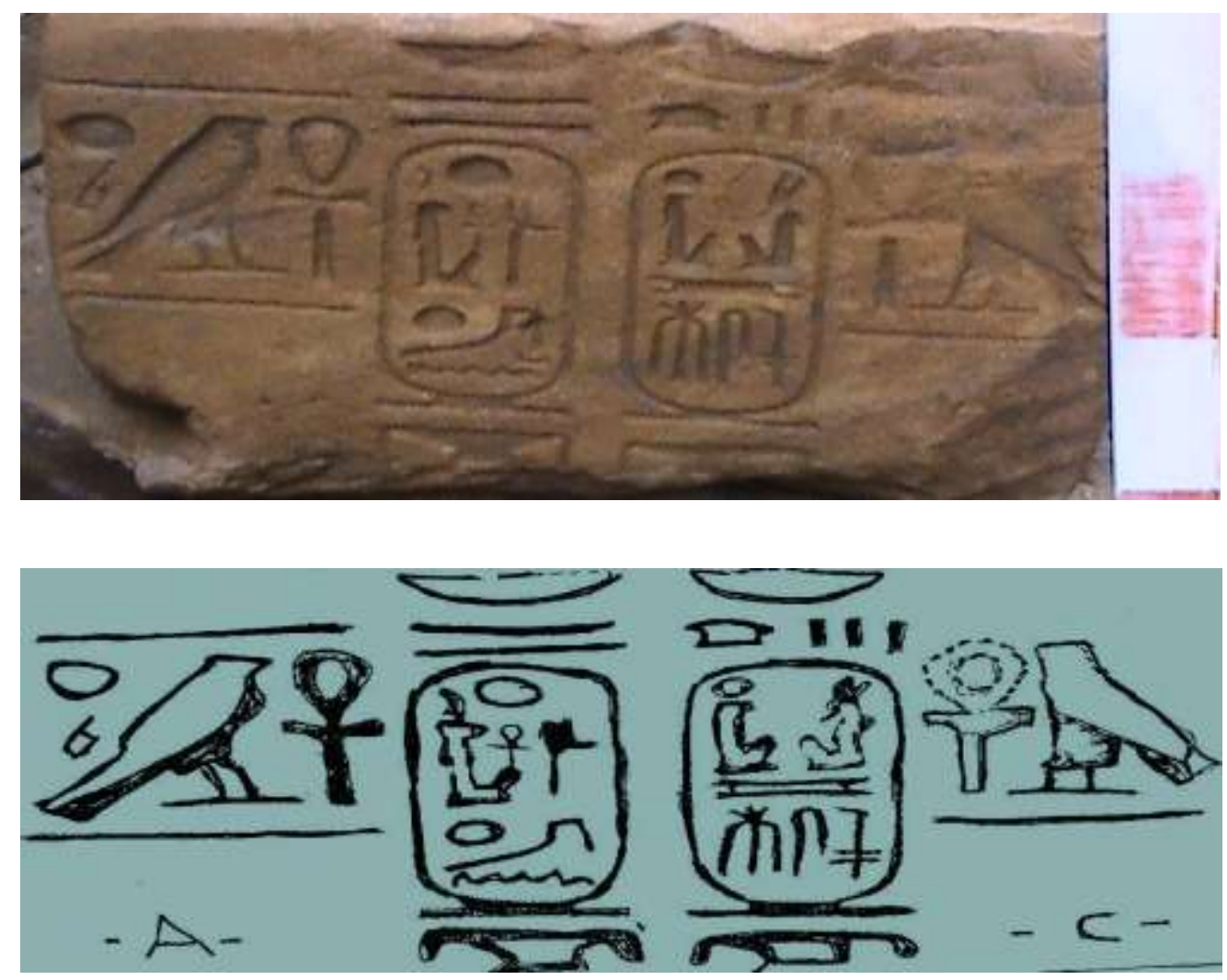

Fig.,2. Front face of offering table : A, C

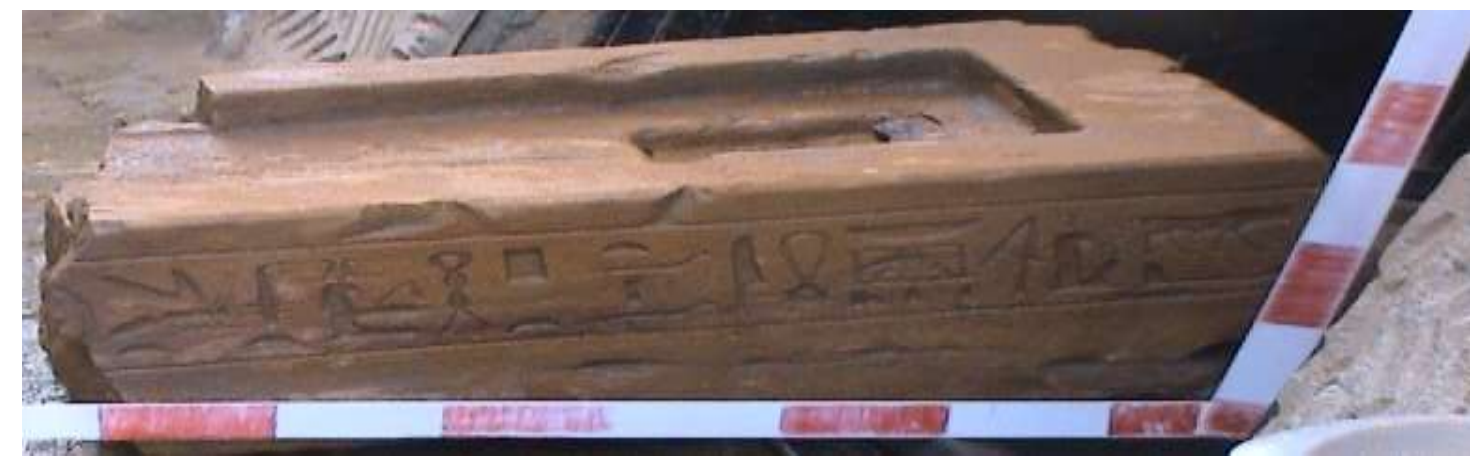




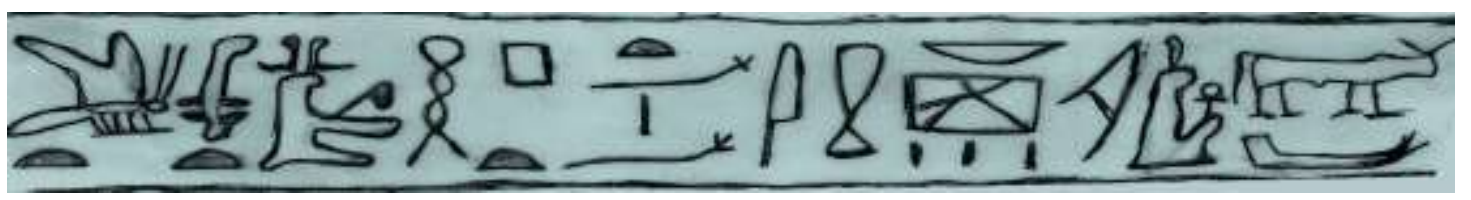

Fig.,3. Left side of offering table : B
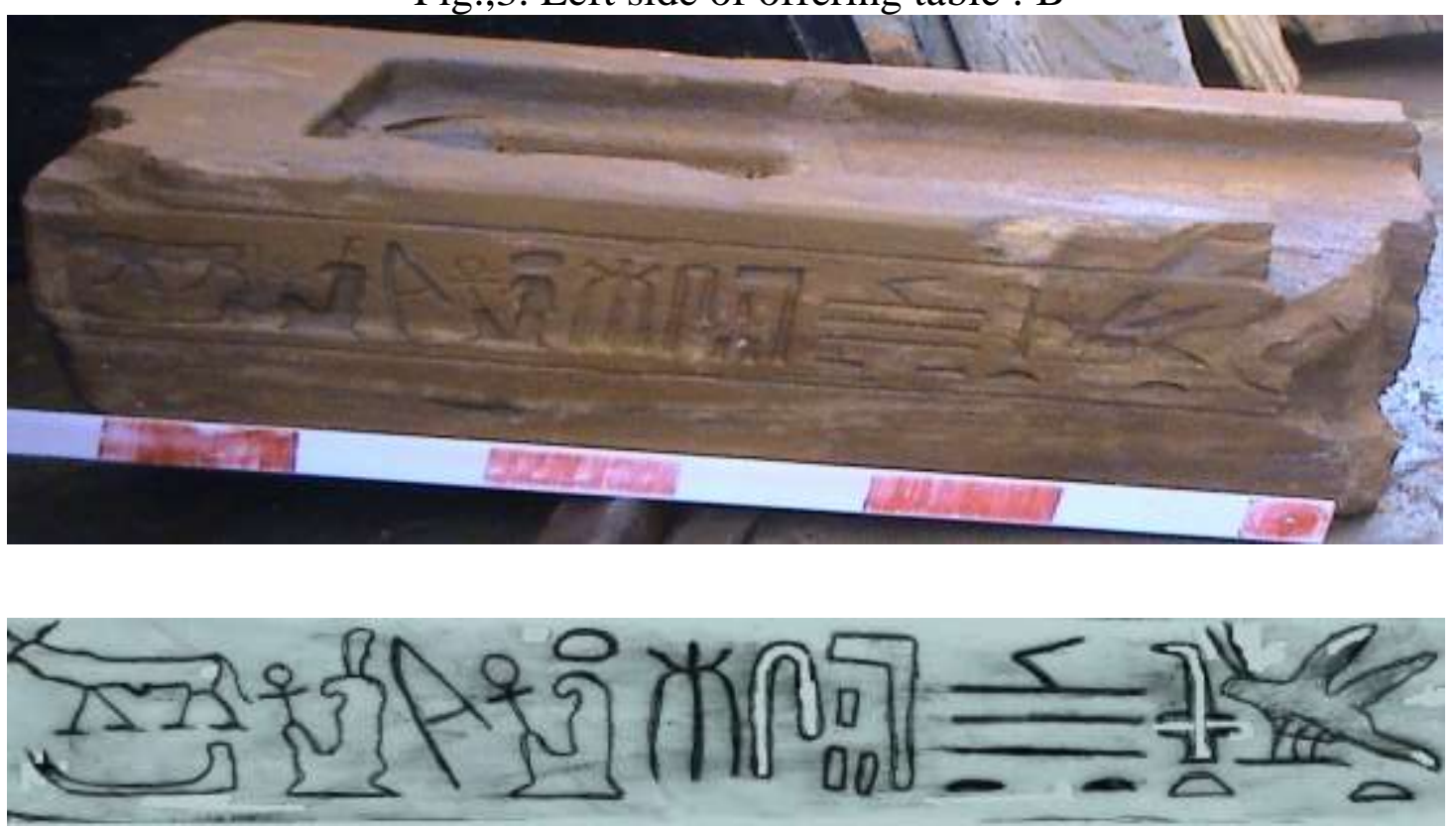

Fig.,4.Right side of the table : D 